\title{
PENGGUNAAN DRAINASE VERTIKAL SATU ARAH PADA TANAH LUNAK DENGAN VARIASI DIAMETER KOLOM PASIR
}

\author{
Wildan Priya Wicaksana1), Bambang Setiawan'2), Niken Silmi Surjandari ${ }^{3}$ ) \\ 1)Mahasiswa Program Studi Teknik Sipil, Fakultas Teknik, Universitas Sebelas Maret \\ 2), 3)Dosen Program Studi Teknik Sipil, Fakultas Teknik, Universitas Sebelas Maret \\ J1. Ir. Sutarmi 36A, Kentingan, Surakarta 57126. Email: wildanpwicakasana@gmail.com
}

\begin{abstract}
Soft soil layer often causes some problems, for instance in the process of embankment construction implementation above the soft soil layer. The subsidence time which relatively long becomes one of the problems in the embankment process. Vertical drainage method is commonly used before the implementation of construction because it can speed up the consolidation process. The principle on how this system works is by forming the drainage channels to the vertical direction (there is one-dimensional consolidation process) so that the underground drainage channels are formed. This study aims to observe the adding process of the sand column as vertical drainage on soft soil. It can be seen from the amount of daily subsidence and accumulative subsidence for 4 weeks or 28 days with diameter variation on $65 \mathrm{~mm}$ diameter rectangular modeling, $40 \mathrm{~mm}$ diameter rectangular modeling, and without vertical drainage. The tests carried out include subsidence, water content, and consolidation. The subsidence on $65 \mathrm{~mm}$ diameter rectangular modeling is 31,04\% and 40,74 bigher than the subsidence on $40 \mathrm{~mm}$ diameter rectangular modeling, and without vertical drainage. The surface settlement that occurs is accompanied by an increase in the water content of the sand and a decrease in soft soil water content whose value is directly proportional to the magnitude of the surface settlement experienced. The results of the consolidation test showed that compretion indekx $\left(C_{c}\right)$ and coefficient of consolidation $\left(C_{v}\right)$ values in the rectangular $65 \mathrm{~mm}$ diameter model are the highest among other models. $C_{c}$ and $C_{v}$ values for rectangular modeling $65 \mathrm{~mm}$ diameter rectangular modeling diameter 40 $\mathrm{mm}$ and without vertical drainage respectively obtained 0.794 and $0.056 \mathrm{~cm} 2 / \mathrm{sec}, 0.756$ and $0.054 \mathrm{~cm} 2 / \mathrm{sec}$ and 0.728 and $0.049 \mathrm{~cm} 2 / \mathrm{sec}$. The addition of vertical drainage on soft soil can accelerate the process of soft soil degradation, and using variations of segie four with a diameter of $60 \mathrm{~mm}$ provides the most effective performance.
\end{abstract}

Keywords: diameter, sand column, vertical drainage

\begin{abstract}
Abstrak
Lapisan tanah lunak sering menimbulkan berbagai permasalahan, misalnya pada proses pelaksanaan konstruksi timbunan yang berada diatas lapisan tanah lunak. Waktu penurunan yang relatif lama menjadi salah satu masalah dalam pekerjaan timbunan. Metode yang sering digunakan sebelum pelaksanaan konstruksi dimulai yaitu dengan penggunaan drainase vertikal dengan tujuan untuk mempercepat proses konsolidasi. Prinsip kerja dari sistem ini adalah dengan terbentuknya saluran drainase kearah vertikal (terjadi proses konsolidasi satu dimensi) sehingga diperoleh lintasan pengaliran di dalam tanah. Penelitian ditujukan untuk melihat perilaku penambahan kolom pasir sebagai drainase vertikal pada tanah lunak yang dilihat dari besar penurunan per hari dan penurunan secara akumulatif selama 4 minggu atau 28 hari dengan variasi diameter pada permodelan segi empat diameter $65 \mathrm{~mm}$, permodelan segi empat diameter $40 \mathrm{~mm}$, dan tanpa drainase vertikal. Pengujian diantaranya penurunan, kadar air, dan konsolidasi. Penurunan paling cepat terjadi pada permodelan diameter $65 \mathrm{~mm}$ yaitu lebih besar 31,04\% dan 40,74\% dari permodelan segi empat diameter $40 \mathrm{~mm}$ dan pemodelan tanpa drainase vertikal. Penurunan permukaan yang terjadi diiringi dengan meningkatnya kadar air pasir dan turunnya kadar air tanah lunak yang nilainya berbanding lurus dengan besarnya penurunan yang dialami. Hasil uji konsolidasi memperlihatkan nilai indeks pemampatan $\left(C_{c}\right)$ dan koefisien konsolidasi $\left(C_{v}\right)$ pada permodelan segi empat diameter $65 \mathrm{~mm}$ paling tinggi diantara pemodelan lainnya. Nilai $C_{c}$ dan $C_{\nu}$ untuk permodelan segi empat diameter $65 \mathrm{~mm}$ permodelan segi empat diameter $40 \mathrm{~mm}$ dan tanpa drainase vertikal berturut-turut didapat sebesar 0,794 dan $0,056 \mathrm{~cm}^{2} /$ detik, 0,756 dan $0,054 \mathrm{~cm}^{2} /$ detik serta 0,728 dan $0,049 \mathrm{~cm}^{2} /$ detik. Penambahan drainase vertikal pada tanah lunak dapat mempercepat proses penurunan tanah lunak, dan menggunakan variasi segie empat dengan diameter $60 \mathrm{~mm}$ memberikan kinerja yang paling efektif.
\end{abstract}

Kata kunci : diameter kolom pasir, drainase vertikal, satu arah.

\section{PENDAHULUAN}

Pekerjaan pembangunan struktur, baik gedung, jembatan, jalan raya, maupun tiang-tiang listrik tidak dipungkiri bahwa tanah menjadi salah satu faktor penting dalam perancanganya. Salah satu pekerjaan tanah yang seringkali dilakukan adalah penimbunan. Salah satu permasalahan yang sering dialami dalam pekerjaan timbunan adalah waktu penurunan atau settlement yang relatif lama, oleh karena itu dikembangkan berberapa metode untuk mengatasinya. Salah satu metode yang digunakan adalah dengan mempercepat keluarnya air pori dari dalam 
tanah menggunakan drainase vertikal atau vertical drain. Salah satu jenis drainase vertikal yang ada yaitu kolom pasir (sand column). Salah satu material yang memiliki permeabilitas yang relatif tinggi adalah pasir. Sifat pasir yang memiliki permeabilitas tinggi membuat air pori leluasa bergerak pada arah vertikal. Sifat pasir tersebut, diharapakan dapat mempercepat keluarnya air pori dari dalam tanah. Selain itu penambahan kolom pasir dapat memperpendek jalur resapan air pada arah horizontal. Maka dari itu muncul gagasan untuk menggunakan kolom pasir sebagai bahan dalam pembuatan drainase vertikal. Efektifitas kinerja drainase vertikal menjadi salah satu hal yang patut di perhatikan, mengingat semakin efisien suatu metode yang digunakan, semakin menguntungkan dalam semua aspek kerja. Studi terdahulu mengenai drainase vertikal telah banyak dilakukan, baik membahas pengaruh jarak, bahan, dan pola, namun mengenai variasi diameter belum dikaji sebelumnya, terkhusus variasi diameter $65 \mathrm{~mm}$ dan $40 \mathrm{~mm}$ pola segi empat. Penelitian ini akan dibahas mengenai pengaruh diameter kolom pasir sebagai drainase vertikal satu arah pada tanah lunak".

\section{LANDASAN TEORI}

Terdapat beberapa penelitian yang telah dilakukan sebelumnya mengenai pengaruh penambahan kolom pasir terhadap perilaku tanah lunak, diantaranya yaitu:

Prastyo dkk (2017) melakukan penelitian mengenai pengaruh kedalaman drainase vertikal kolom pasir terhadap kecepatan konsolidasi dan perubahan kadar air tanah lunak. Berdasarkan hasil penelitian tersebut disimpulkan bahwa kolom pasir dengan rasio kedalaman kolom pasir terhadap ketebalan tanah lunak yang lebih besar akan mengalami penurunan tanah yang lebih cepat.

Penelitian tersebut mengacu pada pernyataan Abadi (2004) yaitu penggunaan drainase vertikal telah sejak lama dilakukan orang. Pasir menjadi bahan utama pengisi drainase vertikal pada saat itu. Tujuan utamanya adalah mempercepat proses penurunan yang akan terjadi pada suatu lapisan tanah tertentu. Penurunan akan cepat terjadi apabila dipasang suatu sistem drainase vertikal untuk memperpendek jarak yang ditempuh air terdisipasi.

Penelitian kali ini melanjukan penelitian dari Prastyo dkk (2017) dengan melakukan beberapa penggantian variasi terhadap diameter kolom pasir dari drainase vertikal satu arah menggunakan kolom pasir. Pola pemasangan yang digunakan yaitu pola segitiga dan segiempat. Pembebanan dilakukan selama 21 hari dan pelepasan beban selama 7 hari, beban yang digunakan seberat $40 \mathrm{~kg}$.

\section{Tanah Lunak}

Hardiyatmo (2002) berpendapat tanah lunak merupakan tanah lempung kohesif yang mempunyai daya dukung lebih kecil dari $0,5 \mathrm{~kg} / \mathrm{cm} 2$ dan nilai standard penetration test lebih kecil dari 4 (N SPT $<4$ ). Berdasarkan uji lapangan, tanah lunak secara fisik dapat diremas dengan mudah oleh jari-jari tangan. Sifat umum tanah lunak adalah me imiliki kadar air $60-110 \%$, batas cair $60 \%$ - $100 \%$, batas plastis $30 \%-50 \%$, kuat geser $20 \mathrm{kN} / \mathrm{m}^{2}$ hingga $40 \mathrm{kN} / \mathrm{m}^{2}$ dan saat diuji dengan analisis saringan butiran yang lolos oleh saringan no. 200 adalah lebih besar dari $85 \%$.

\section{Pasir}

Menurut Bowles (1983) pasir merupakan partikel-partikel tambang yang lebih kecil dari kerikil dengan ukuran butiran antara $0,05 \mathrm{~mm}$ sampai $0,074 \mathrm{~mm}$. Pasir adalah bahan yang tak berkohesi, akan tetapi jika pasir tersebut lembab atau mengandung uap air maka tegangan permukaan memberikan kohesi yang nyata. Kohesi tersebut juga akan menghilang bila pasir mengering atau menjadi jenuh.

\section{Konsolidasi Tanah}

Konsolidasi adalah proses dimana tekanan air pori berlebih akibat peningkatan tegangan pada lapisan tanah sehingga air pori terdisipasi dari dalam tanah. Semakin tinggi nilai permeabilitas tanah maka semakin cepat waktu konsolidasi dan sebaliknya. Tanah kohesif mempunyai waktu konsolidasinya panjang karena sifat permeabilitasnya yang rendah.

Uji konsolidasi yang dilakukan menghasilkan parameter-parameter konsolidasi tanah, yaitu koefisien konsolidasi $\left(C_{v}\right)$ dan indeks pemampatan $\left(C_{c}\right)$. Parameter $C_{v}$ digunakan untuk menghitung tingkat kecepatan penurunan tanah, $C_{v}$ dapat dicari dengan menggunakan metode Taylor (akar waktu). Besarnya nilai $C_{c}$ adalah kemiringan dari bagian lurus grafik $e-\log$ hasil pengujian konsolidasi di laboratorium.

Nilai $C_{c}$ laboratorium perlu dikonversikan menjadi $C_{c}$ lapangan, kemudian dapat digunakan untuk mencari nilai penurunan konsolidasi lapisan tanah menggunakan persamaan sebagai berikut:

$$
S_{c} \quad=C_{c} \frac{H}{1+e_{0}} \log \frac{\sigma_{0}+\Delta \sigma}{\sigma_{0}}
$$

dengan, 


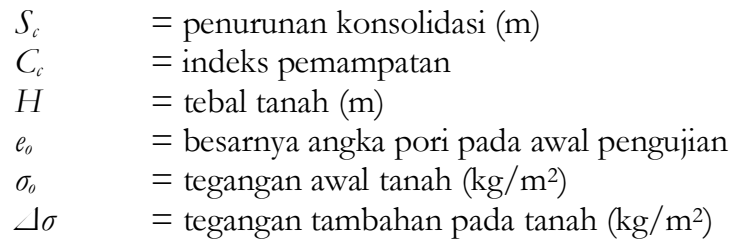

\section{METODE PENELITIAN}

Metode penelitian yang digunakan dalam penelitian ini adalah pengamatan langsung melalui pemodelan fisik skala kecil di laboratorium. Penelitian dilakukan di Laboratorium Mekanika Tanah Program Studi Teknik Sipil Universitas Sebelas Maret Surakarta. Sampel tanah diambil dari Dusun Seneng, Desa Girimargo, Kecamatan Miri, Kabupaten Sragen.

\section{Tahap Persiapan}

Tahap ini meliputi uji pendahuluan sampel tanah dan persiapan media tanah lunak dan pasir. Uji pendahuluan diperlukan untuk memastikan apakah sampel tanah yang diambil termasuk tanah lunak. Persiapan media dilakukan guna menyeragamkan kondisi tanah lunak dan pasir yang digunakan untuk setiap model.

\section{Tahap Perakitan Model}

Terdapat dua model yang dibuat, yaitu permodelan pola segiempat $\varnothing 40 \mathrm{~mm}$ dan Permodelan pola segiempat $\varnothing 65 \mathrm{~mm}$. Selain dua model utama di atas, dibuat pula model tanpa drainase vertikal yang digunakan sebagai acuan. Dibuat kolom pasir dengan diameter $40 \mathrm{~mm}$ dan $65 \mathrm{~mm}$ sedalam $25 \mathrm{~cm}$ dengan jarak antar pusat kolom pasir sebesar $10 \mathrm{~cm}$.

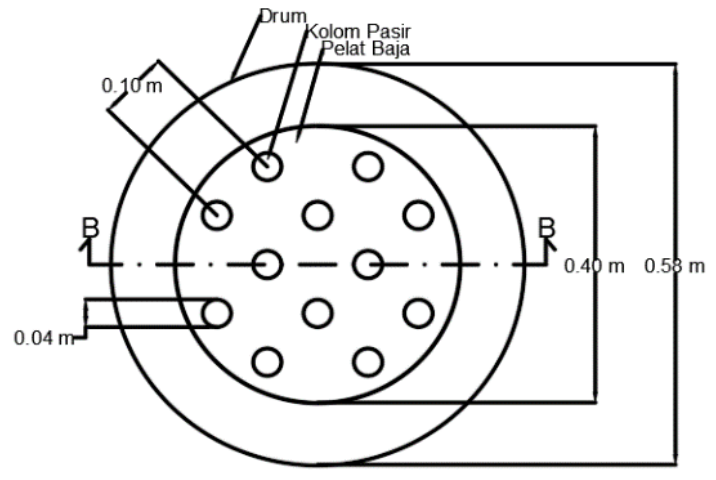

(a)

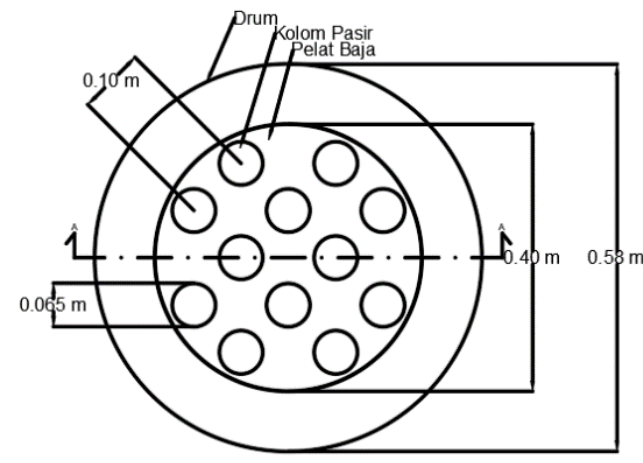

(b)

Gambar 1 Detail tampak atas permodelan (a) diameter $40 \mathrm{~mm}$ (b) diameter $65 \mathrm{~mm}$

\section{Tahap Penelitian Utama}

Pengujian dilakukan dengan memberikan beban seberat $40 \mathrm{~kg}$ yang diletakkan di atas pelat selama 21 hari yang dilanjutkan dengan proses unloading selama 7 hari. Selama kurun waktu tersebut diperhatikan hal-hal sebagai berikut:

a. Pengukuran nilai $C_{c}$ dan $C_{\nu}$ tanah lunak.

b. Pengukuran penurunan elevasi plat harian dengan jangka sorong.

c. Pengukuran kadar air tiga harian pada tanah lunak dan pasir pada lapis porus permukaan.

\section{ANALISIS DATA DAN PEMBAHASAN}

Uji pendahuluan yang dilakukan menunjukkan bahwa sampel tanah memenuhi syarat sebagai tanah lunak dengan nilai batas cair (liquid limit) sebesar $91,44 \%$, batas plastis (plastic limit) sebesar 47,67 \% dan persentase lolos saringan 200 sebesar $98,27 \%$.

\section{Penurunan}

Pengujian penurunan dilakukan pada sampel tanah sebelum pembebanan dan juga setelah dilakukan pembebanan baik dari sampel model uji tanpa drainase vertikal + beban, permodelan segi empat $\varnothing 40 \mathrm{~mm}$ dan permodelan segi empat $\varnothing 65 \mathrm{~mm}$. 


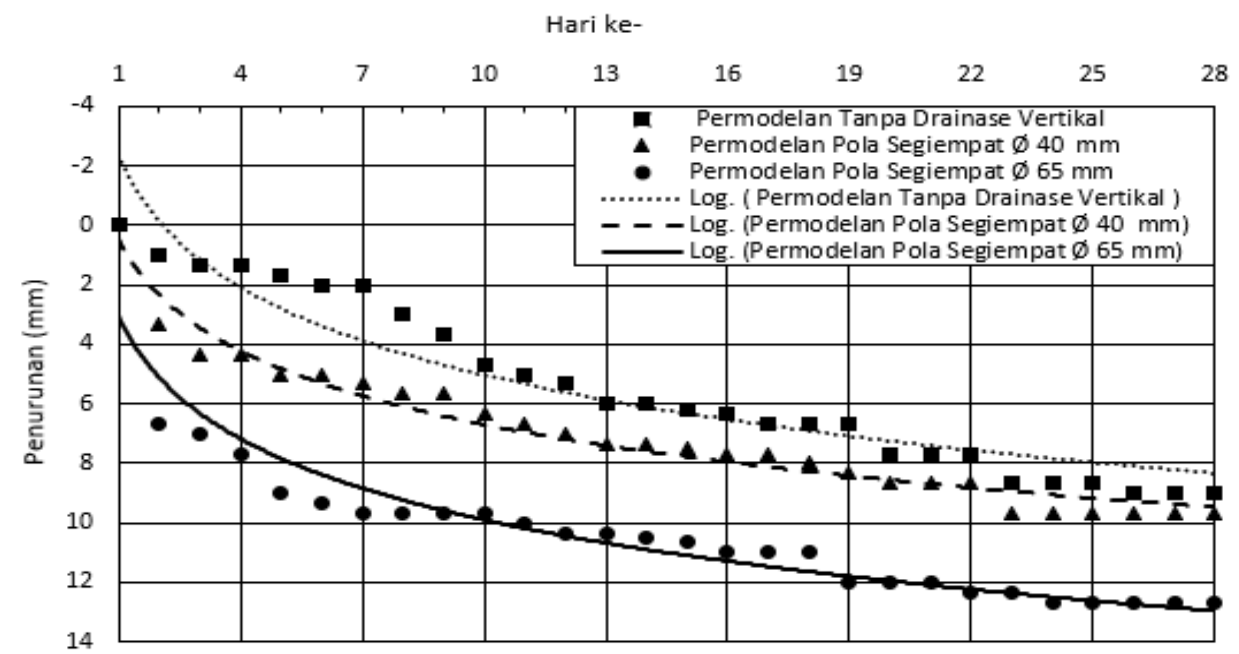

Gambar 2 Grafik penurunan permukaan tanah untuk tiap model

Pada gambar 2 menunjukan permodelan pola segiempat $\varnothing 65 \mathrm{~mm}$ memiliki laju penurunan tercepat, dengan nilai penurunan sebesar $12,67 \mathrm{~mm}$, kemudian disusul permodelan pola segiempat $\varnothing 40 \mathrm{~mm}$ dengan nilai penurunan sebesar 9,67 mm dan terakhir adalah permodelan tanpa drainase vertikal dengan nilai penurunan sebesar $9 \mathrm{~mm}$. Penurunan yang terjadi pada permodelan pola segiempat $\varnothing 65 \mathrm{~mm}$ lebih besar dan lebih cepat dikarenakan cakupan resapan air lebih pendek dan lebih banyak sehingga air pori mampu keluar lebih cepat saat terjadi pemampatan.

\section{Kadar Air Pasir}

Hasil pengukuran kadar air pasir pada lapis porus permukaan untuk setiap model dapat dilihat pada Gambar 3 di bawah ini.

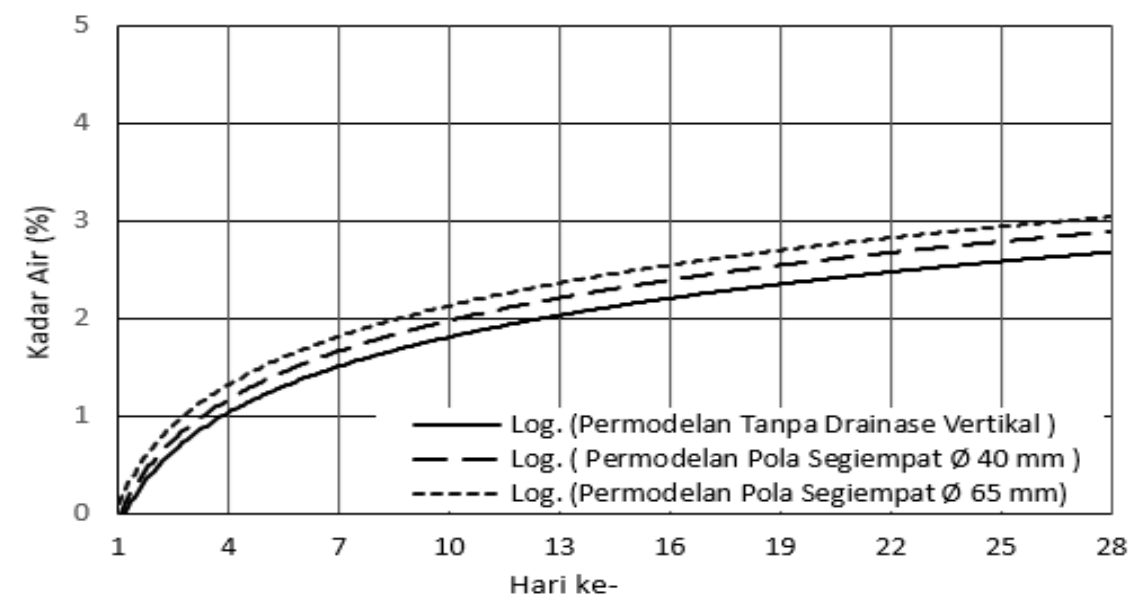

Gambar 3 Grafik kadar air pasir untuk tiap model

Pada gambar 3 menunjukan permodelan tanpa drainase vertikal memiliki kadar air pasir rata-rata sebesar 1,85 $\%$., lalu untuk pemodelan pola segiempat $\varnothing 40 \mathrm{~mm}$ memiliki kadar air pasir rata-rata 2,03 \% dan pemodelan pola segiempat $\varnothing 65 \mathrm{~mm}$ memiliki kadar air pasir rata-rata 2,18\%. Penambahan kolom pasir dapat mempercepat proses peresapan air dengan kinerja paling baik dimiliki pemodelan pola segiempat $\varnothing 65 \mathrm{~mm}$. Daerah kerja yang lebih rapat pada susunan pola segitiga membuat air pori lebih mudah meresap ke dalam kolom-kolom pasir yang ada untuk kemudian disalurkan ke lapisan pasir pada lapis porus dasar dan permukaan.

Kadar Air Tanah Lunak

Hasil pengukuran kadar air tanah lunak untuk setiap model dapat dilihat pada Gambar 4 di bawah ini. 


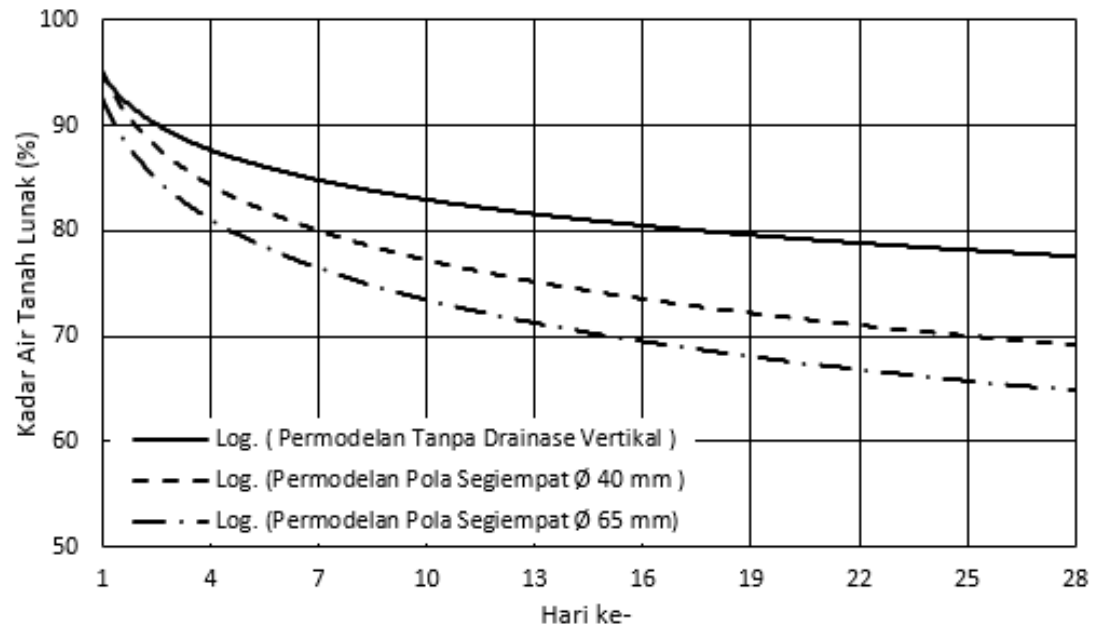

Gambar 4 Grafik kadar air tanah lunak untuk tiap model

Pada gambar 4 menunjukan permodelan tanpa drainase vertikal memiliki kadar air tanah lunak rata-rata 82,67 $\%$, lalu untuk Pemodelan segiempat Ø $40 \mathrm{~mm}$ memiliki kadar air tanah lunak rata-rata 76,80\% serta pemodelan pola segiempat $\varnothing 65 \mathrm{~mm}$ memiliki kadar air tanah lunak rata-rata $73 \%$. Penambahan kolom pasir dapat mempercepat proses peresapan air pori keluar dari tanah lunak. Daerah kerja yang lebih rapat pada pemodelan pola segiempat $\varnothing 65 \mathrm{~mm}$ membuat air pori lebih mudah meresap ke dalam kolom-kolom pasir yang ada untuk kemudian disalurkan ke lapisan pasir permukaan Hasilnya pemodelan pola segiempat $\varnothing 65 \mathrm{~mm}$ memiliki kemampuan penyaluran air dari tanah lunak menuju kolom pasir, paling cepat diantara ketiga model uji.

Uji Konsolidasi Tanah Lunak

Pengujian konsolidasi dilakukan pada sampel tanah baik sebelum maupun setelah pembebanan, diperoleh hasil seperti yang ditunjukkan dalam Tabel 1 di bawah ini.

Tabel 1 Rekapitulasi hasil uji konsolidasi untuk setiap model

\begin{tabular}{llllll}
\hline Sampel Tanah & $C_{v}$ & & & $t$ & \\
& $\left(\mathrm{~cm}^{2} /\right.$ detik $)$ & & & & $S_{c}$ Lab. \\
& $C_{c}$ Lap. & (detik) & \\
\hline Permodelan Tanpa Beban & 0,042 & 0,607 & 0,869 & 12585,98 & - \\
\hline Permodelan Tanpa Drainase Vertikal & 0,049 & 0,728 & 1,093 & 10809,17 & 24,343 \\
\hline Permodelan Pola Segiempat $\varnothing 40 \mathrm{~mm}$ & 0,054 & 0,756 & 1,201 & 9762,07 & 24,371 \\
\hline Permodelan Pola Segiempat $\varnothing 65 \mathrm{~mm}$ & 0,056 & 0,794 & 1,539 & 9390,35 & 25,431 \\
\hline
\end{tabular}

Pada 1 menunjukan pemodelan pola segiempat $\varnothing 65 \mathrm{~mm}$ nilai $C_{v}$ tertinggi sebesar $0,056 \mathrm{~cm} 2 /$ detik, ini menunjukkan bahwa model tersebut memiliki kecepatan konsolidasi tertinggi. Nilai $C_{c}$ lapangan tertinggi juga dimiliki model ini sebesar 0,794, ini menunjukkan bahwa pad a model tersebut telah mengalami pemampatan yang terbesar.

Waktu konsolidasi $(t)$ dihitung berdasarkan nilai $C_{v}$, nilai $t$ paling singkat dimiliki pemodelan pola segiempat $\varnothing$ $65 \mathrm{~mm}$ sebesar 9390,35 detik, semakin besar nilai $C_{v}$ maka waktu yang dibutuhkan untuk mencapai derajat konsolidasi sebesar $90 \%$ akan semakin cepat. Model tersebut juga memiliki besar penurunan konsolidasi $\left(S_{c}\right)$ teoritis tertinggi sebesar $25,431 \mathrm{~mm}$, semakin besar nilai $C_{c}$ maka penurunan konsolidasi teoritis yang dihasilkan juga akan semakin besar pula.

\section{Perbandingan Penurunan Konsolidasi Hasil Pengamatan dengan Hasil Analisis}

Hasil analisis perhitungan penurunan konsolidasi $\left(S_{c}\right)$ teoritis yang telah dilakukan sebelumnya kemudian dibandingkan dengan penurunan permukaan hasil pengamatan dari model yang telah dibuat di laboratorium seperti yang ditunjukkan pada Tabel 2 . 
Tabel 2 Perbandingan penurunan hasil analisis dan pengamatan pada hari ke- 28

\begin{tabular}{lccc}
\hline \multicolumn{1}{c}{ Sampel Tanah } & \multicolumn{3}{c}{$\boldsymbol{S}_{\boldsymbol{c}}(\mathbf{m m})$} \\
\cline { 2 - 4 } & Pengamatan & Analisis & Selisih \\
\hline Permodelan tanpa drainase vertikal & 9,000 & 24,343 & 15,343 \\
\hline Permodelan pola segiempat $\varnothing 40 \mathrm{~mm}$ & 9,667 & 24,371 & 14,705 \\
\hline Permodelan pola segiempat $\varnothing 65 \mathrm{~mm}$ & 12,667 & 25,431 & 12,764 \\
\hline
\end{tabular}

Pada tabel 2 menunjukan pemodelan pola segiempat $\varnothing 65 \mathrm{~mm}$ memiliki nilai $S_{c}$ hasil pengamatan dan analisis perhitungan tertinggi sebesar 25,431 $\mathrm{mm}$ dan 12,667 dengan selisih penurunan sebesar 12,764 mm disusul dengan pemodelan pola segiempat $\varnothing 40 \mathrm{~mm}$ dengan nilai Sc hasil pengamatan dan analisis perhitungan sebesar 24,371 $\mathrm{mm}$ dan 9,667 mm dengan selish penurunan sebesar 14,705 serta pemodelan tanpa drainase vertikal dengan nilai $S_{c}$ hasil pengamatan dan analisis perhitungan sebesar 24,343 $\mathrm{mm}$ dan $9,000 \mathrm{~mm}$ dengan selisih penurunan sebesar $15,343 \mathrm{~mm}$.

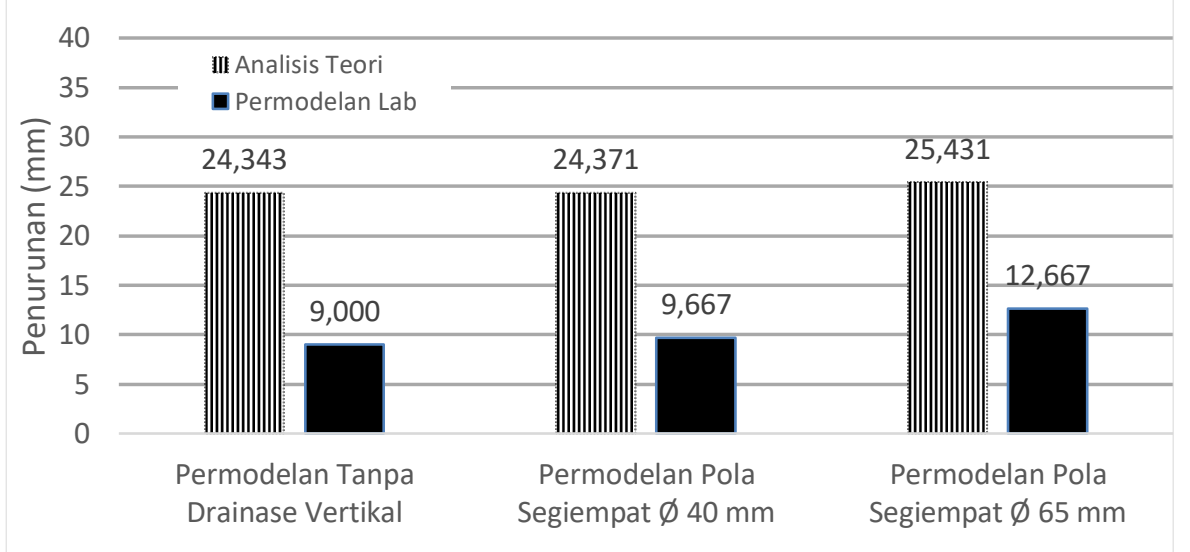

Gambar 5 Graifik perbandingan penurunan antara hasil analisis dan pengamatan pada hari ke- 28

Gambar 5 menunjukkan adanya selisih yang cukup besar antara penurunan konsolidasi hasil pengamatan dengan analisis perhitungan, namun keduanya memiliki kecenderungan tren yang sama. Setiap model juga memiliki selisih penurunan konsolidasi antara hasil pengamatan dengan analisis perhitungan yang berdekatan, hal ini memperlihatkan adanya korelasi yang sama diantara keduanya.

\section{SIMPULAN}

Berdasarkan penelitian yang telah dilakukan dapat diambil beberapa kesimpulan sebagai berikut:

1. Hasil pengamatan penurunan selama 28 hari diperoleh permodelan pola segiempat $\varnothing 65$ memiliki penurunan paling cepat dengan kemampuan resapan air ke lapisan pasir permukaan paling cepat yaitu 2,18 $\%$ untuk kadar air lapisan pasir permukaan dan $73 \%$ untuk kadar air tanah lunak.

2. Kadar air lapisan pasir permukaan akan bertambah apabila terjadi penurunan, sedangkan kadar air tanah lunak akan berkurang apabila terjadi penurunan pada tanah lunak baik yang menggunakan drainase vertikal maupun tidak.

3. Permodelan pola segiempat $\varnothing 65$ memiliki nilai $C_{v}$ sebesar $0,056 \mathrm{~cm} 2 /$ detik, nilai $C_{c}$ sebesar 0,0794 lalu menghasilkan nilai $S_{c}$ sebesar $0,794 \mathrm{~mm}$. Nilai $C_{c}$ semakin besar maka nilai penurunan atau pemampatan tanah lunak hasil analisis $\left(S_{c}\right)$ yang terjadi juga akan semakin besar.

\section{REKOMENDASI}

1. Dicoba bahan alternatif lain selain pasir sebagai media drainase vertikal.

2. Ketebalan pasir pada lapisan dasar dibuat bervariatif.

3. Media pasir yang digunakan sebagai bahan drainase vertikal dibuat dengan gradasi yang lebih spesifik dan bervariatif.

\section{REFERENSI}


Abadi, T. C., 2004, Uji Laboratorium Pemanfaatan Serabut Kelapa dan Ijuk Sebagai Bahan Drainase Vertikal Tanpa Filter, Jurusan Teknik Sipil, Institut Teknologi Nasional Bandung.

Hardiyatmo, H. C. 2002. Mekanika Tanah II. Yogyakarta: Gadjah Mada University Press.

Listyawan, A. B., Wiqoyah, Q., Renaningsih dan Satriyana, M. R. W. 2015. Pengaruh Kolom Pasir Terhadap Konsolidasi Tanah Lempung Lunak. Eco Rekayasa. 11 (1): 23-27.

Sandhyavitri, Wibisono, G., Juniati, S., dan Rioputra, M., D., 2008. Analisa Perbaikan Sub-Grade Runway Lapangan Terbang Dengan Metode Vertical Drain (Studi Kasus Bandara Tempuling Di Tembilahan, Propinsi Riau), Jurusan Teknik Sipil, Universtias Riau .

Terzaghi, K., Peck, R. B. dan Mesri, G. 1996. Soil Mechanics in Engineering Practice. New York: John Willey \& Sons, Inc.

Prastyo, B., Setiawan, B., Indrabaskara, R. H. D. H., 2017. Pengaruh Kedalaman Drainase Vertikal Satu Arah Menggunakan Kolom Pasir terhadap Kecepatan Penurunan dan Perubahan Kadar Air Tanah Lunak, Program Studi Teknik Sipil, Universitas Sebelas Maret. 